DOI: 10.17707/AgricultForest.62.4.02

\author{
Ibolya DEMETER, \\ Marianna MAKÁDI, Attila TOMÓCSIK, \\ Tibor ARANYOS, Katalin POSTA ${ }^{I}$
}

\title{
MICROBIAL COMMUNITY PROFILES IN RESPONSE TO DIFFERENT SOIL MANAGEMENTS IN SANDY SOIL
}

\begin{abstract}
SUMMARY
The growing human population has higher and higher food demand, which requires an increase in efficiency of agricultural production. Healthy and fertile soils are essential to satisfy this demand. The microbial community structure is an excellent indicator of the soil fertility and the diversity of bacteria and fungi. In our work we compared the effect of organic and conventional cultivation methods on the microbial community profiles of sandy soils in the Nyírség region, Hungary. These fields have topographical heterogeneity therefore the sampling sites were divided into top of hill and bottom of hill. Sampling was done in autumn 2013, from the $0-30 \mathrm{~cm}$ and the $30-60 \mathrm{~cm}$ soil depths. The phospholipid fatty acids (PLFA) were used for the monitoring of microbial community. PLFAs break down when the cell dies therefore these molecules show the community structure in a real time. In the $0-30 \mathrm{~cm}$ soil layer of organically managed field the PLFA structure was significantly different between top and bottom of hill, but the difference were low. In conventionally managed field, high differences were found between the PLFA groups measured in the top and bottom of hill. The PLFA values were higher in the top of hill in organic field, while in case of bottom of hills sites higher PLFA values were measured in conventional farming system. In the deeper soil layers the tendencies were found similar to the upper soil layer, but the measured values were lower.
\end{abstract}

Keywords: cultivation system, microbial community structure, PLFA, topography, soil depth

\section{INTRODUCTION}

The soil microbial community largely determines the soil fertility by influencing the dynamics of organic matter and nutrient cycles (Liu et al., 2006; Bowles et al., 2014). These microbes are responsible for breakdown of dead plant residues and turning those to the carbon cycle. Higher microbial activity and biodegradation were observed in the ecological or reduced tillage cultivation than in conventional management system (Ge et al., 2013; Mangalaserry et al., 2015).

\footnotetext{
${ }^{1}$ Ibolya Demeter, (corresponding author: ibolyad85@gmail.com), Marianna Makádi, Attila Tomócsik, Tibor Aranyos, Research Institute of Nyíregyháza, University of Debrecen, 4400 Nyíregyháza, HUNGARY, Katalin Posta, Plant Protection Institute, Szent István University, 2100 Gödöllö, HUNGARY.

Paper presented at the $7^{\text {th }}$ International Scientific Agricultural Symposium "AGROSYM 2016".

Notes: The authors declare that they have no conflicts of interest. Authorship Form signed online.
} 
Therefore it is important to apply properly selected cultivation method, which results in favourable conditions for the soil microbes (Prasad et al., 2016).

Before 1989 intensive farming was conducted in large fields with large volume of the used cheap pesticides and fertilizers. The harmful effects of agricultural chemicals to the biodiversity and human health have already known (Snedeker, 2001; Colborn et al., 1993). Nowadays, in Hungary the use of sustainable agricultural methods is preferred (Birkás et al., 2004).

The objective of this study was to compare the effects of ecological and conventional farming systems on microbiological properties of soil. We investigated the effects of studied management systems and the modification effects of relief of the studied area, and we observed the stronger effect of management compared to the relief.

\section{MATERIALS AND METHODS}

The sampling sites are located in the Nyírség region, in the north-eastern part of Hungary, where the main soil type is acidic sand (Arenosols). In this region the climate is moderately cold-dry. In the investigated year the main annual temperature was $12.5{ }^{\circ} \mathrm{C}$ and the annual precipitation was $486 \mathrm{~mm}$ in sampling areas. Because of the topographical heterogeneity of this region, samples were collected from top of hills and bottom hills.

Sampling sites were the followings:

1. Ecological, top of hill (ET) $\left(214036^{\circ} 82^{\prime} \mathrm{E}, 475849^{\circ} 17^{\prime} \mathrm{N}, 156 \mathrm{~m}\right.$ above sea level);

2. Ecological, bottom of hill (EB) $\left(214031^{\circ} 48^{\prime} \mathrm{E}, 475848^{\circ} 81^{\prime} \mathrm{N}, 151 \mathrm{~m}\right.$ above sea level);

3. Conventional, top of hill (CT) $\left(214051^{\circ} 10^{\prime} \mathrm{E}, 475841^{\circ} 35^{\prime} \mathrm{N}, 158 \mathrm{~m}\right.$ above sea level);

4. Conventional, bottom of hill (CB) (214054⒍ $64^{\prime} \mathrm{E}, 475842^{\circ} 43^{\prime} \mathrm{N}, 153 \mathrm{~m}$ above sea level).

The studied areas located at the Research Institute of Nyíregyháza, Debrecen University, where the ecological crop production has been carrying since 1997. In the studied sampling period, rye was cultivated in both management systems. In both cultivation methods ploughing was applied up to $30 \mathrm{~cm}$ depth and deep loosening up to $60 \mathrm{~cm}$ depth in every $5^{\text {th }}$ year. In conventional area the bottom of hill was liming in autumn 2012 because of the low $\mathrm{pH}(3.89 \pm 0.03)$ of soil.

Samples were collected in autumn 2013 (22 and 24 October), from two depths, $0-30 \mathrm{~cm}$ and the $30-60 \mathrm{~cm}$, in four repetitions (one repetition was a composite sample of four point samples). Samples were stored frozen before analysis. The soil temperature was varied in the range between $10.9-17.5^{\circ} \mathrm{C}$ in the sampling days.

Before the chemical analysis the larger plant roots were removed in the laboratory, and the air dried samples were sieved $(\varnothing 2 \mathrm{~mm})$. The $\mathrm{pH}_{\mathrm{KCl}}$ was measured with a Hach-Lange, HQ411D type digital $\mathrm{pH}$ meter (Hach-Lange, 
Loveland, Colorado, USA) where the soil : $\mathrm{KCl}$ ratio was $1: 2.5$. Total carbon (C) and nitrogen $(\mathrm{N})$ content were determined by Dumas method (varioMax CNS, Elementar Analysensysteme GmbH, Hanau, Germany). The organic carbon content was calculated from the humus content, which was measured with an UNICAM UV2 spectrophotometer (Thermo Scientific, Waltham, Massachusetts, USA), after the digestion with potassium dichromate and cc. sulphuric acid.

The nitrite-nitrate-N content was measured with a FIA Star 5000 device (Foss, Hilleroed, Denmark), from potassium chloride extracts.

The PLFAs were prepared as described by White et al. (White et al., 1979) with some modifications, in four repetitions. Briefly, $10.00 \mathrm{~g}$ (frozen, then incubated and sieved) soil was extracted using a single-phase chloroformmethanol-phosphate buffer system, during $2 \mathrm{~h}$ with a laboratory shaker.

Then we added chloroform and distilled water to this extract, and filtrated in celite. The filtrate was separated with shaker funnel for the bottom chloroform phase. After the sodium sulphate filtration and vacuum evaporation of the chloroform phase, the phospholipids were separated from neutral lipids and glycolipids using silica acid columns (Chromabond, Macherey Nagel, Germany), followed by methylation of the phospholipids. Samples were stored at $-20^{\circ} \mathrm{C}$ until the analysis. Methyl nonadecanoate was used as internal standard after the methylation. The PLFAs were separated and identified using a gas chromatograph-mass spectrometer system (GC 6890N with MS 5975, Agilent, Santa Clara, CA, USA) with a $100 \mathrm{~m}$ Supelco SP-2560 column, in selected ion mode and scan mode as well (50-350 amu).

Gerstel MPS2 autosampler was used for the injection, the injection volume was $3 \mu 1$. The PLFAs 14:0, 15:0, 16:0 and 18:0 represented the general bacterial biomass. The branched, saturated PLFAs, as iC15:0, aC15:0, iC16:0, iC17:0, aC17:0 were used as $\mathrm{Gram}^{+}$as well as the monoenoic and cyclopropane unsaturated $\mathrm{C} 16: 1 \mathrm{n} 7 \mathrm{c}, \mathrm{C} 16: 1 \mathrm{n} 5 \mathrm{c}, \mathrm{C} 18: 1 \mathrm{n} 9 \mathrm{c}$, cyC19:0 as Gram biomarkers. The 10MeC16:0 and 10MeC17:0 represented the Actinobacteria, and $\mathrm{C} 18: 2 \mathrm{n} 6$ was used as fungi marker. These PLFAs were used to calculate total PLFA concentration (nmol PLFA g ${ }^{-1}$ dry soil). On the bases of measured PLFAs the ratios of these groups were calculated.

All measurements were reported as mean values with standard errors, where statistical analysis was done using internal repetitions respectively $(n=4)$. IBM SPSS Statistics 22.0 software package (IBM Inc., USA) were used for statistical analyses at $\mathrm{P}=0.05$ significance level.

One-way analysis of variance (ANOVA) was used for comparing the means of different sampling sites followed by Games-Howell and Tukey-b test. Correlations between investigated parameters were determined using Pearson's correlation.

\section{RESULTS AND DISCUSSION}

Generally, the measured values of $\mathrm{pH}_{\mathrm{KCl}}$ fit in the $\mathrm{pH}$ range of most acidic sandy soils (4.02-7.01). Furthermore acidifying effect of fertilizer was also 
observed (Pais et al., 1990) in conventional top of hill, but in conventional bottom of hill the liming was resulted in higher $\mathrm{pH}_{\mathrm{KCl}}$ in autumn 2013. Compared to the two farming systems, favourable chemical values were measured in ecological field on the top of hill, except the inorganic $\mathrm{N}$ (Table 1), but at the bottom of hill the investigated parameters were higher in conventional field. The available nitrogen and carbon usually increased with increasing $\mathrm{pH}$ (Zhao et al., 2011). Generally, the most investigated parameters were higher in upper (0-30 $\mathrm{cm}$ ) soil layer and also were higher in the bottom of hill, than in top of hill (except of nitrite-nitrate-N in ecological field). In ecological top of hill significantly higher total and organic carbon were observed and recycled plant residues increased the total nitrogen content and carbon: nitrogen ratio (Chen et al., 2000; Edmeades, 2003).

Table 1. The main chemical parameters of investigated soils

\begin{tabular}{|c|c|c|c|c|c|c|}
\hline $\begin{array}{c}\text { Sampling } \\
\text { site }\end{array}$ & $\mathrm{pH}_{\mathrm{KCl}}$ & total $\mathrm{C}^{*}$ & organic $\mathrm{C}^{*}$ & total $\mathrm{N}^{*}$ & $\begin{array}{c}\mathrm{NO}_{2} \mathrm{NO}^{-}- \\
\mathrm{N}^{*}\end{array}$ & $\mathrm{C}: \mathrm{N}$ ratio \\
\hline $\begin{array}{c}\mathrm{ET} 0-30 \\
\mathrm{~cm}\end{array}$ & $5.43 \pm 0.01 \mathrm{c}$ & $0.497 \pm 0.02 \mathrm{~b}$ & $0.372 \pm 0.02 \mathrm{~b}$ & $0.055 \pm 0.00 \mathrm{~b}$ & $0.019 \pm 0.00 \mathrm{~b}$ & $9.026 \pm 0.06 \mathrm{~b}$ \\
\hline $\begin{array}{c}\mathrm{ET} 30-60 \\
\mathrm{~cm}\end{array}$ & $5.53 \pm 0.17 \mathrm{C}$ & $0.332 \pm 0.06 \mathrm{~B}$ & $0.232 \pm 0.06 \mathrm{~B}$ & $0.040 \pm 0.00 \mathrm{~B}$ & $0.010 \pm 0.00 \mathrm{C}$ & $8.241 \pm 0.17 \mathrm{C}$ \\
\hline $\begin{array}{c}\mathrm{EB} 0-30 \\
\mathrm{~cm}\end{array}$ & $4.85 \pm 0.06 \mathrm{~b}$ & $0.818 \pm 0.01 \mathrm{c}$ & $0.715 \pm 0.02 \mathrm{c}$ & $0.093 \pm 0.00 \mathrm{c}$ & $0.010 \pm 0.00 \mathrm{ab}$ & $\begin{array}{c}8.839 \pm 0.01 \mathrm{a} \\
\mathrm{b}\end{array}$ \\
\hline $\begin{array}{c}\mathrm{EB} 30-60 \\
\mathrm{~cm}\end{array}$ & $5.05 \pm 0.35 \mathrm{~B}$ & $0.721 \pm 0.01 \mathrm{C}$ & $0.589 \pm 0.08 \mathrm{C}$ & $0.083 \pm 0.00 \mathrm{C}$ & $0.007 \pm 0.00 \mathrm{~B}$ & $8.658 \pm 0.35 \mathrm{~B}$ \\
\hline $\begin{array}{c}\text { CT 0-30 } \\
\mathrm{cm}\end{array}$ & $4.02 \pm 0.04 \mathrm{a}$ & $0.346 \pm 0.00 \mathrm{a}$ & $0.202 \pm 0.00 \mathrm{a}$ & $0.040 \pm 0.00 \mathrm{a}$ & $0.008 \pm 0.00 \mathrm{a}$ & $8.751 \pm 0.06 \mathrm{a}$ \\
\hline $\begin{array}{c}\text { CT 30-60 } \\
\mathrm{cm}\end{array}$ & $4.15 \pm 0.09 \mathrm{~A}$ & $0.222 \pm 0.06 \mathrm{~A}$ & $0.100 \pm 0.08 \mathrm{~A}$ & $0.029 \pm 0.00 \mathrm{~A}$ & $0.004 \pm 0.00 \mathrm{~A}$ & $7.488 \pm 0.09 \mathrm{C}$ \\
\hline $\begin{array}{c}\mathrm{CB} 0-30 \\
\mathrm{~cm}\end{array}$ & $7.01 \pm 0.01 \mathrm{~d}$ & $0.943 \pm 0.02 \mathrm{~d}$ & $0.729 \pm 0.01 \mathrm{c}$ & $0.096 \pm 0.00 \mathrm{c}$ & $0.020 \pm 0.00 \mathrm{~b}$ & $9.778 \pm 0.09 \mathrm{c}$ \\
\hline $\begin{array}{c}\text { CB 30-60 } \\
\mathrm{cm}\end{array}$ & $6.61 \pm 0.44 \mathrm{D}$ & $0.735 \pm 0.08 \mathrm{C}$ & $0.524 \pm 0.06 \mathrm{C}$ & $0.081 \pm 0.00 \mathrm{C}$ & $0.009 \pm 0.00 \mathrm{BC}$ & $9.116 \pm 0.44 \mathrm{D}$ \\
\hline
\end{tabular}

${ }^{\mathrm{a}}$ Data are expressed as mean \pm standard errors $(\mathrm{n}=12)$.

${ }^{\mathrm{b}}$ Within a column followed by different letters represent the differences by one-way ANOVA followed by Games-Howell test $(\mathrm{P}<0.05)$.

The management practice affected not only the soil chemical parameters, but also the structure of microbial community. The nutrient supply method has strong effect on the community structure, through the differences of organic matter content, and the value of available substrates (Hartman et al., 2006), and the change of $\mathrm{pH}$ affect the structure of microbial community (Rousk et al., 2009). The General bacteria $\left(2.12 \pm 0.00\right.$ nmol PLFA g ${ }^{-1}$ dry soil), Gram ${ }^{+}$ $\left(1.59 \pm 0.00\right.$ nmol PLFA g ${ }^{-1}$ dry soil $)$ and Gram $^{-}\left(2.05 \pm 0.00\right.$ nmol PLFA g ${ }^{-1}$ dry soil) bacteria, Actinobacteria $\left(0.48 \pm 0.00\right.$ nmol PLFA g ${ }^{-1}$ dry soil) and Fungi $\left(0.32 \pm 0.00 \mathrm{nmol}\right.$ PLFA $\mathrm{g}^{-1}$ dry soil) markers were highest in upper soil layer in conventional bottom of hill, while the lowest values were measured in conventional top of hill (Table 2). In case of these markers and the total PLFA significant differences were observed between two reliefs, but compared to the 
two farming systems, the differences were lower in ecological, than the conventional farming system. Furthermore in ecological field the values of measured markers and total PLFA were higher in top of hill, but in conventional plots were higher in bottom of hill. The $\mathrm{pH}$ influences of microbial community (Bååth \& Anderson, 2003) and liming could cause the increased PLFA values of CB site.

Table 2. Structure of microbial community in autumn 2013

\begin{tabular}{|c|c|c|c|c|c|c|c|c|}
\hline \multirow{2}{*}{$\begin{array}{c}\text { PLFA } \\
\text { markers }\end{array}$} & \multicolumn{2}{|c|}{ ET } & \multicolumn{2}{|c|}{ EB } & \multicolumn{2}{|c|}{ CT } & \multicolumn{2}{|c|}{ CB } \\
\hline & $0-30 \mathrm{~cm}$ & $30-60 \mathrm{~cm}$ & $0-30 \mathrm{~cm}$ & $30-60 \mathrm{~cm}$ & $0-30 \mathrm{~cm}$ & $30-60 \mathrm{~cm}$ & $0-30 \mathrm{~cm}$ & $30-60 \mathrm{~cm}$ \\
\hline \multirow{2}{*}{$\begin{array}{c}\text { General } \\
\text { bacteria }^{a}\end{array}$} & $1.30 \pm 0.00$ & $1.07 \pm 0.00$ & $1.2 \pm 0.00$ & $0.69 \pm 0.00$ & $0.75 \pm 0.00$ & $0.72 \pm 0.00$ & $2.12 \pm 0.00$ & $1.08 \pm 0.00$ \\
\hline & $\mathrm{c}$ & $\mathrm{C}$ & $\mathrm{b}$ & A & $\mathrm{a}$ & B & $\mathrm{d}$ & D \\
\hline \multirow{2}{*}{$\begin{array}{c}\mathrm{Gram}^{+} \\
\text {bacteria }^{\mathrm{a}}\end{array}$} & $1.05 \pm 0.00$ & $0.98 \pm 0.00$ & $1.04 \pm 0.00$ & $0.43 \pm 0.00$ & $0.53 \pm 0.00$ & $0.55 \pm 0.00$ & $1.59 \pm 0.00$ & $0.73 \pm 0.00$ \\
\hline & $\mathrm{c}$ & D & $\mathrm{b}$ & $\mathrm{A}$ & $\mathrm{a}$ & B & $\mathrm{d}$ & $\mathrm{C}$ \\
\hline \multirow{2}{*}{$\begin{array}{c}\text { Gram }^{-} \\
\text {bacteria }^{\text {a }}\end{array}$} & $0.97 \pm 0.00$ & $0.74 \pm 0.00$ & $1.08 \pm 0.00$ & $0.46 \pm 0.00$ & $0.50 \pm 0.00$ & $0.45 \pm 0.00$ & $2.05 \pm 0.00$ & $0.84 \pm 0.00$ \\
\hline & $\mathrm{b}$ & $\mathrm{C}$ & $\mathrm{c}$ & B & $\mathrm{a}$ & $\mathrm{A}$ & $\mathrm{d}$ & D \\
\hline \multirow{2}{*}{$\begin{array}{c}\text { Actinobacteri } \\
\mathrm{a}^{\mathrm{a}}\end{array}$} & $0.38 \pm 0.00$ & $0.16 \pm 0.00$ & $0.35 \pm 0.00$ & $0.17 \pm 0.00$ & $0.17 \pm 0.00$ & $0.27 \pm 0.00$ & $0.48 \pm 0.00$ & $0.42 \pm 0.00$ \\
\hline & $\mathrm{c}$ & $\mathrm{A}$ & $\mathrm{b}$ & $\mathrm{B}$ & $\mathrm{a}$ & $\mathrm{C}$ & $\mathrm{d}$ & D \\
\hline \multirow{2}{*}{$\begin{array}{c}\text { Fungi } \\
\text { (C18:2n6) }^{\mathrm{a}}\end{array}$} & $0.13 \pm 0.00$ & $0.08 \pm 0.00$ & $0.10 \pm 0.00$ & $0.03 \pm 0.00$ & $0.05 \pm 0.00$ & $0.05 \pm 0.00$ & $0.32 \pm 0.00$ & $0.11 \pm 0.00$ \\
\hline & c & C & b & A & $\mathrm{a}$ & B & $\mathrm{d}$ & D \\
\hline \multirow{2}{*}{$\begin{array}{c}\text { Gram }^{+}: \\
\text {Gram ratio }\end{array}$} & $0.92 \pm 0.00$ & $0.76 \pm 0.00$ & $1.05 \pm 0.00$ & $1.05 \pm 0.00$ & $0.95 \pm 0.00$ & $0.82 \pm 0.00$ & $1.29 \pm 0.00$ & $1.16 \pm 0.00$ \\
\hline & $\mathrm{a}$ & A & $\mathrm{c}$ & $\mathrm{C}$ & $\mathrm{b}$ & B & $\mathrm{d}$ & D \\
\hline \multirow{2}{*}{$\begin{array}{c}\text { Fungi: } \\
\text { General } \\
\text { bacteria ratio }\end{array}$} & $0.10 \pm 0.00$ & $0.07 \pm 0.00$ & $0.08 \pm 0.00$ & $0.04 \pm 0.00$ & $0.07 \pm 0.00$ & $0.07 \pm 0.00$ & $0.15 \pm 0.00$ & $0.11 \pm 0.00$ \\
\hline & c & $\mathrm{C}$ & $b$ & A & $\begin{array}{c}a \\
\mathrm{a}\end{array}$ & B & $\mathrm{d}$ & D \\
\hline \multirow{2}{*}{$\begin{array}{c}\text { Actinobacteri } \\
\text { a:General } \\
\text { bacteria ratio }\end{array}$} & $0.30 \pm 0.00$ & $0.39 \pm 0.00$ & $0.29 \pm 0.00$ & $0.25 \pm 0.00$ & $0.23 \pm 0.00$ & $0.22 \pm 0.00$ & $0.22 \pm 0.00$ & $0.25 \pm 0.00$ \\
\hline & $\mathrm{d}$ & D & $\mathrm{c}$ & C & $\mathrm{b}$ & A & $\mathrm{a}$ & B \\
\hline \multirow{2}{*}{ Total PLFA } & $3.83 \pm 0.00$ & $3.29 \pm 0.00$ & $3.77 \pm 0.00$ & $1.78 \pm 0.00$ & $2.00 \pm 0.00$ & $1.92 \pm 0.00$ & $6.56 \pm 0.00$ & $3.02 \pm 0.00$ \\
\hline & $\mathrm{c}$ & D & b & A & $\mathrm{a}$ & B & d & $\mathrm{C}$ \\
\hline
\end{tabular}

${ }^{a}$ Data are expressed as mean (nmol PLFA g ${ }^{-1}$ dry soil) \pm standard errors $(n=4)$.

${ }^{\mathrm{b}}$ Within a raw different letters represent the differences of means according to one-way ANOVA followed by Tukey-b test $(\mathrm{P}<0.05)$, the lowercases $(\mathrm{a}-\mathrm{d})$ are marked the results of $0-30 \mathrm{~cm}$ soil layer and capital letters (AD) are marked the results of $30-60 \mathrm{~cm}$ soil layer.

Low proportion of easily available carbon source increases the value of $\mathrm{Gram}^{+}$bacteria (Esperschütz et el., 2007), while values of Gram ${ }^{-}$bacteria markers was increased when the quantity of easily available, unstable carbon forms were increased in the soil (Peacock et al., 2001). Therefore, the measured lower Gram ${ }^{+}$ : Gram bacteria ratio in ET and CT indicates higher value of easily available carbon forms in this sites.

The increasing organic matter input results in increase of fungi, thereby the increase of Fungi : Bacteria ratio (Frostegård et al., 1996). We measured higher Fungi values from upper soil layer in conventional bottom of hill and the ecological top of hill, but the organic carbon was higher in the two bottom of hill and the fungi was higher in the CB and ET, there was not significant relationship 
between the two parameters. The value of fungi depends also on the $\mathrm{pH}$. When the $\mathrm{pH}$ lower, the conditions are unfavourable for bacteria, and the fungi community increases (Rousk et al., 2009). However, we not found negative correlation between the values of Fungi and $\mathrm{pH}(0.467, \mathrm{P}<0.01)$. The relationship between $\mathrm{pH}$ and general bacteria markers was significantly positive $(0.455, \mathrm{P}<0.01)$

Higher ratio of Actinobacteria: General bacteria in ecological field indicated the progressed decomposition process in sampling time, opposite in conventional field (Bastida et al., 2013).

\section{CONCLUSIONS}

Ecological management had favourable effect on the chemical parameters and microbial community of sandy soils in Nyírség region. The lower differences between two reliefs in ecological field were resulted by favourable conditions and better buffer capacity of soil, providing protection against extreme environmental events. The positive effect of liming was also observed, like increasing $\mathrm{pH}$ and microbial biomass in conventional bottom of hill. However, additional studies are needed to understand changes of Fungi : bacteria ratio with increasing $\mathrm{pH}$. Our results revealed that regular recycling of organic matter after harvesting without artificial fertilizer utilization could maintain the fertility of sandy soils.

\section{ACKNOWLEDGEMENT}

This work was supported by the Hungarian Research Institute of Organic Agriculture (ÖMKi). We thank Antal Ferenczy† for his valuable advices in the statistical evaluation.

\section{REFERENCES}

Bååth E., Anderson T.-H. (2003). Comparison of soil fungal/bacterial ratios in a pH gradient using physiological and PLFA-based techniques, Soil Biology \& Biochemistry (35) 955-963.

Bastida F., Torres I. F., Hernández T., Bombach P., Richnow H. H., García C. (2013). Can the labile carbon contribute to carbon immobilization in semiarid soils? Priming effects and microbial community dynamics, Soil Biology \& Biochemistry (57) 892-902.

Birkás M., Jolánkai M., Gyuricza C., Percze A. (2004). Tillage effects on compaction, earthworms and other soil quality indicators in Hungary, Soil \& Tillage Research (78) $185-196$.

Bowles T. M., Acosta-Martínez V., Calderón F., Jackson L. E. (2014). Soil enzyme activities, microbial communities, and carbon and nitrogen availability in organic agroecosystems across an intensively-managed agricultural landscape, Soil Biology \& Biochemistry (68) 252-262.

Chen C., Condron L.M., Davis M., Sherlock R.R. (2000). Effects of afforestation on phosphorus dynamics and biological properties in a New Zealand grassland soil, Plant and Soil (220) 151-163. 
Colborn T., vom Saal F. S., Soto A. M. (1993). Developmental Effects of EndocrineDisrupting Chemicals in Wildlife and Humans, Environmental Health Perspectives (101) 378-384.

Edmeades D.C. (2003). The long-term effects of manures and fertilizers on soil productivity and quality: a review, Nutrient Cycling in Agroecosystems (66) 165180.

Esperschütz J., Gattinger A., Mäder P., Schloter M., Fliessbach A. (2007). Response of soil microbial biomass and community structures to conventional and organic farming systems under identical crop rotations. FEMS Microbiology Ecology (61) 26-37.

Frostegård A., Bååth E. (1996). The use of phospholipids fatty acid analysis to estimate bacterial and fungal biomass in soil, Biology and Fertility of Soils (22) 59-65.

Ge T., Chen X., Yuan H., Li B., Zhu H., Peng P., Li K., Jones D. L., Wu J. (2013). Microbial biomass, activity, and community structure in horticultural soils under conventional and organic management strategies, European Journal of Soil Biology (58) 122-128.

Hartman M., Fliessbach A., Oberholzer H.R., Widmer F. (2006). Ranking the magnitude of crop and farming system effects on soil microbial biomass and genetic structure of bacterial communities, FEMS Microbiology Ecology (57) 378-388.

Liu X., Herbert S.J., Hashemi A.M., Zhang X., Ding G. (2006). Effects of agricultural management on soil organic matter and carbon transformation, Plant, Soil and Environment (52) 531-543.

Mangalassery S., Mooney S.J., Sparkes D.L., Fraser W.T., Sjögersten S. (2015). Impacts of zero tillage on soil enzyme activities, microbial characteristics and organic matter functional chemistry in temperate soils, European Journal of Soil Biology (68) 9-17.

Pais I., Horváth L. (1990). Atmospheric Acidic Deposition and Ist Environmental Effect in Hungary, in: Bresser A. H. M. and Salomons W. (Eds.), Advances in Environmental Science, Acidic Precipitation, New-York, pp. 193-214.

Peacock A.D., Macnaughton S.J., Cantu J.M., Dale V.H., White D.C. (2001). Soil microbial biomass and community composition along an anthropogenic disturbance gradient within a long-leaf pine habitat, Ecological Indicators (1) 113121.

Prasad J.V.N.S., Srinivasa Rao Ch., Srinivas K., Naga Jyothi Ch., Venkateswarlu B., Ramachandrappa B.K., Dhanapal G.N., Ravichandra K., Mishra P.K. (2016). Effect of ten years of reduced tillage and recycling of organic matter on crop yields, soil organic carbon and its fractions in Alfisols of semi arid tropics of southern India, Soil \& Tillage Research (156) 131-139.

Rousk J., Brookes P. C., Bååth E. (2009). Contrasting soil pH effects on fungal and bacterial growth suggest functional redundancy in carbon mineralization, Applied and Environmental Microbiology (75) 1586-1596.

Snedeker S. (2001) Pesticides and breast cancer risk: a review of DDT, DDE and dieldrin, Environmental Health Perspectives (109) 35- 47.

White D. C., Davis W. M., Nickels J. S., King J. D., Bobbie R. J. (1979). Determination of the sedimentary microbial biomass by extractible lipid phosphate, Oecologia (40) 51-62.

Zhao J., Dong Y., Xie X., Li X., Zhang X., Shen X. (2011). Effect of annual variation in soil $\mathrm{pH}$ on available soil nutrients in pear orchards, Acta Ecologica Sinica (31) 212-216. 